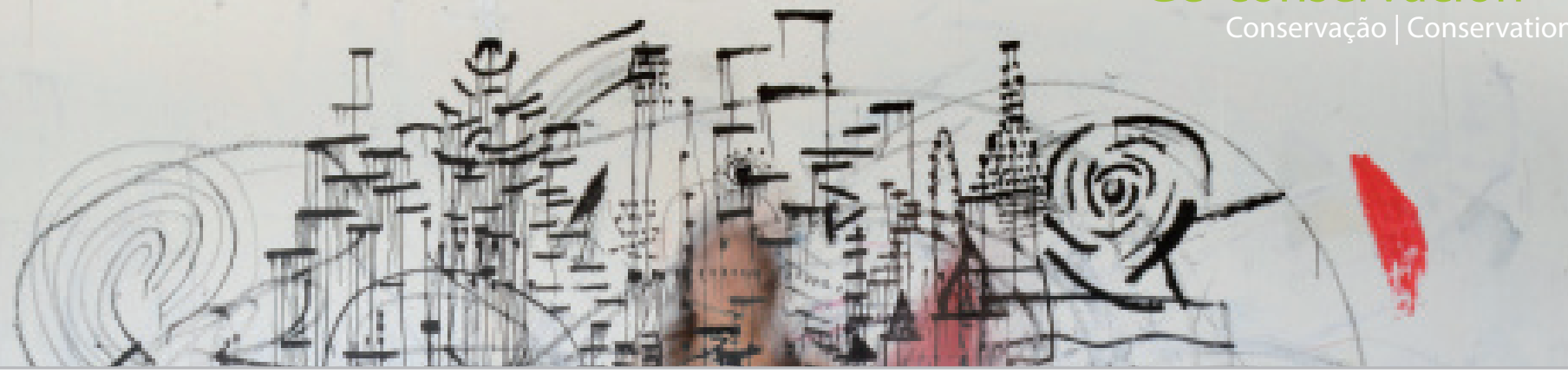

\title{
La colección Parkett de Cuenca a través de la obra de Susan Rothenberg. La importancia de conocer los materiales que conforman el arte contemporáneo
}

\author{
Cristina Peña Ruiz
}

\begin{abstract}
Resumen: La colección Parkett de la Facultad de Bellas Artes de Cuenca es un ejemplo del desafío que supone la conservación de una colección de arte contemporáneo, constituida por una gran complejidad y diversidad de materiales inestables que pueden llegar a configurar muchas de las obras. Los artistas de la colección Parkett emplean desde materiales más tradicionales, como barro sin cocer o soporte de papel, hasta los más desarrollados por la industria como los plásticos.

En el presente caso de estudio se expondrá el trabajo de investigación realizado sobre una de las obras de la colección realizada en látex por la artista Susan Rothenberg y la importancia que supone el conocimiento de dichos materiales para poder establecer unas pautas de conservación preventiva sobre cada una de las obras. La importancia de la investigación de este tipo de materiales resulta indispensable; por dicho motivo se incluyen análisis de espectro infrarrojo, estudios colorimétricos, así como ensayos de envejecimiento acelerado aplicados a diferentes probetas de experimentación.
\end{abstract}

Palabras clave: Conservación contemporánea, Parkett, documentación, Bellas Artes Cuenca, elastómero, conservación preventiva

\section{The Parkett Collection Through Susan Rothenberg's Artwork. The Importance of Knowing the Materials in Contemporary Art}

Abstract: The Parkett Collection of the Faculty of Fine Arts of Cuenca is an example of the great challenge conserving a complex contemporary art collection formed by a diversity of unstable materials used in the production of artworks. The artworks in the Parkett collection include from traditional materials such as clay and works on paper to industrially developed contemporary materials like plastics.

In this case, this paper presents the research carried out on one of the collection pieces made in latex by the artist Susan Rothenberg and the importance of knowledge of the materials to establish bespoke preventive conservation guidelines for each of the works. Researching and analysing this type of materials is indispensable; therefore we present infrared spectrum, colorimetry studies, as well as studies of accelerated ageing tests applied to different specimens are included.

Keywords: Contemporary conservation, Parkett, documentation, Fine Arts Cuenca, elastomer, preventive conservation

\section{Introducción}

El presente artículo se contextualiza a partir de una edición múltiple de la artista Susan Rothenberg, existente en una colección de arte contemporáneo perteneciente a una universidad pública. En este sentido se trata de la colección Parkett de la Facultad de Bellas Artes de Cuenca, que recibe ese nombre en el momento que la coleccionista Helga de Alvear decidió donar su colección Parkett particular a la Universidad de Castilla-La Mancha, hace más de una década,

\section{Introduction}

The present paper is contextualised based on a limited edition artwork series by the artist Susan Rothenberg, part of a contemporary art collection belonging to a public university. The Parkett collection, of the Faculty of Fine Arts of Cuenca, was named when more than a decade ago, the collector Helga de Alvear decided to donate her private Parkett collection to the University of Castilla-La Mancha. Her aim was making the collection 
con el objetivo de poner a disposición la colección para la comunidad universitaria. La universidad recibió gratamente la donación de la coleccionista y creó un espacio expositivo en la propia Facultad de Bellas Artes para uso y disfrute de los docentes, investigadores, estudiantes, artistas, así como personas interesadas de la propia ciudad de Cuenca [Figura 1]. available to the university community. The university was pleased to receive the collector's donation and created an exhibition space in the Faculty of Fine Arts for the use and enjoyment of teachers, researchers, students, artists, and interested people from the city of Cuenca [Figure 1].

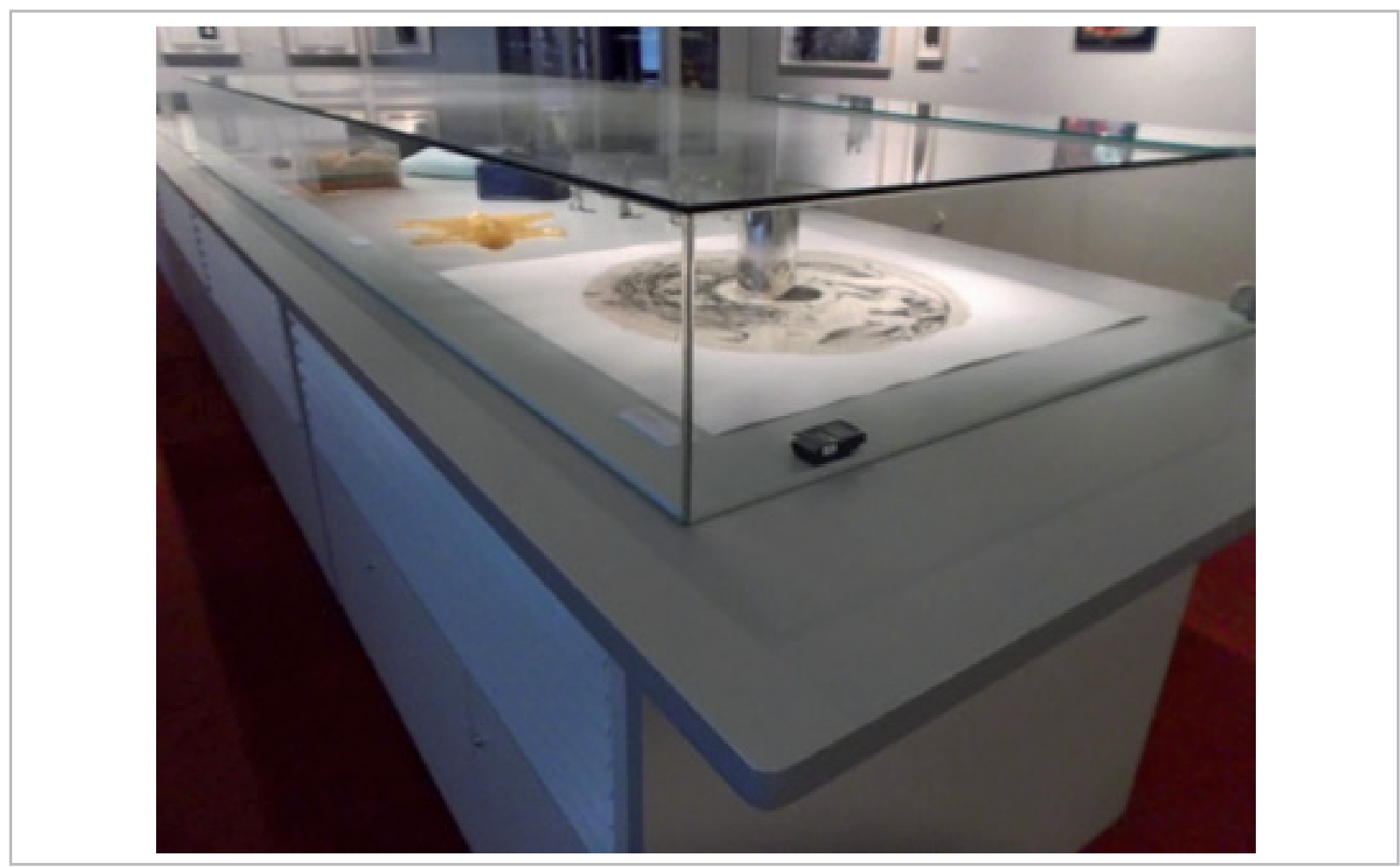

Figura/Figure 1.- Vista del espacio expositivo con el medidor de Ta y HR en una de las vitrinas de la sala Parkett de la Facultad de Bellas Artes de Cuenca en donde se aprecia la edición de Susan Rothenberg. / View of the exhibition space with the Ta and RH meter in one of the showcases in the Parkett showroom at the Faculty of Fine Arts in Cuenca, where the Susan Rothenberg edition can be seen.

\section{La revista Parkett}

Se puede decir que el verdadero origen de la colección se generó como fruto de una revista, la conocida revista Parkett, surgida en los años ochenta del pasado siglo, gracias a un equipo multidisciplinar de profesionales especializados en el ámbito de la edición, crítica, comisariado y gestión artística contemporánea principalmente [Figura 2]. Estos expertos fueron capaces de crear ediciones de obra múltiple en cada uno de los números de las revistas mediante una serie de artistas colaboradores de reconocido prestigio internacional.

La revista se fundó en Zúrich con la vocación de crear un puente a través del arte entre Europa y Estados Unidos. Ese fue el motivo principal del empleo del idioma alemán e inglés en cada una de las publicaciones. Actualmente, mantiene redacciones en ambas orillas del Atlántico, en Zúrich y Nueva York, a pesar de que la revista dejara de publicarse en formato físico en verano de 2017 con su número 100/101. El alcance de esta publicación especializada en arte llegó a niveles insospechables en un principio por los editores, estimando que contaban con unos 30.000 lectores en cuarenta países diferentes.

\section{Parkett magazine}

One might say that the true origin of the collection was generated as a result of a magazine, the well-known Parkett magazine. It emerged in the eighties of the last century, thanks to a multidisciplinary team of professionals specialised in publishing, criticism, curatorship and contemporary art management [Figure 2]. These experts included a limited edition artwork in each issue of the magazines through a series of collaborating artists of international renown.

The magazine was founded in Zurich to create a bridge through art between Europe and the United States. This was the main reason for the use of German and English languages in each of the publications. Today, it maintains editorial offices on both sides of the Atlantic, in Zurich and New York, although the magazine ceased publication in physical format in summer 2017 with its 100/101st issue. This specialised art publication reached initially unsuspected levels by the editors, estimating that they had some 30,000 readers in forty different countries. 


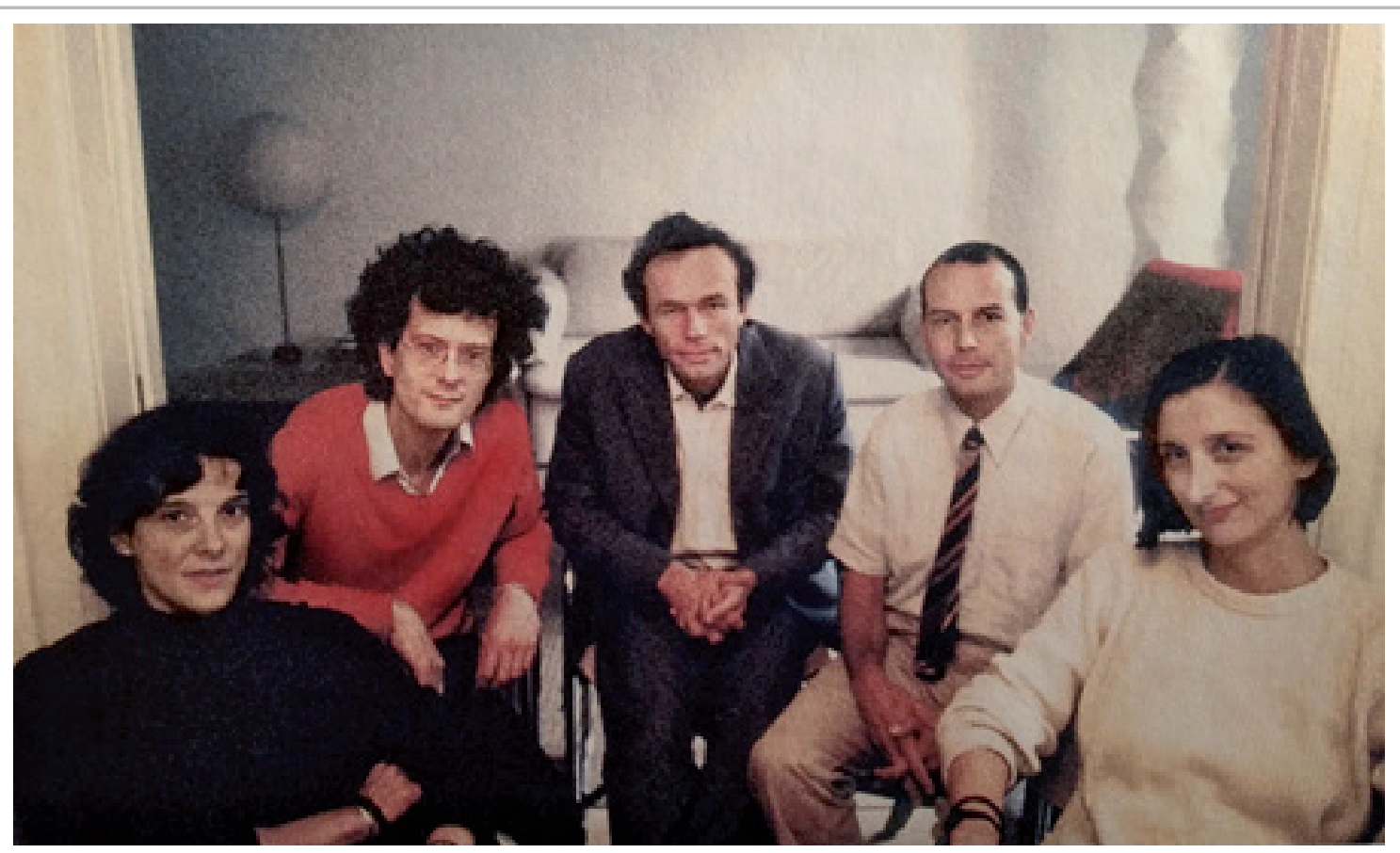

Figura/Figure 2.- Fundadores del proyecto Parkett: Jacqueline Burckhardt, Walter Keller, Dieter von Graffenried, Peter Blum y Bice Curiger (Fotografía de archivo Parkett) / Founders of the Parkett project: Jacqueline Burckhardt, Walter Keller, Dieter von Graffenried, Peter Blum and Bice Curiger (Parkett archive photo).

Se debe destacar que han sido tres décadas de publicaciones donde los editores no solo se han limitado a estudiar la obra de muchos de los artistas más representativos del panorama contemporáneo internacional sino que, además, éstos han colaborado directamente con cada uno de ellos. Igualmente, se debe destacar que se ha completado con textos sobre más de 400 artistas a cargo de un equipo multidisciplinar de críticos, escritores, historiadores del arte y curadores de reconocido prestigio en la actualidad.

Debidoa la cantidad de ensayos críticos reunidos en cada una de las revistas, han llegado a formar una biblioteca representativa del arte contemporáneo en la que las colaboraciones artísticas se han manifestado de diferentes formas: en los lomos, cubiertas e incluso en el interior de cada una de las mismas. La Facultad de Bellas Artes de Cuenca también cuenta con la colección completa de estas revistas, así como ediciones especiales. Además, estas son objeto de préstamo a través del servicio de la biblioteca de la Universidad Castilla-La Mancha.

\section{Las colaboraciones artísticas en Parkett}

Una vez presentada la revista, se debe destacar que lo más representativo de la creación de ésta es, sin duda, la presencia de las colaboraciones artísticas y la cooperación entre editorialartista. Ésta fue tan enriquecedora que los llevó a crear ediciones originales, firmadas y numeradas, que ponían a la venta y ofrecían a sus suscriptores, para que así tuvieran la posibilidad de formar una pequeña colección de arte contemporáneo para disfrutar en casa, al ser la inmensa mayoría de las mismas de pequeño formato. Parkett se describe a sí misma como "un pequeño museo y una gran biblioteca de arte contemporáneo" ${ }^{\prime[1]}$. Obviamente, no todos los suscritos a la revista adquirieron desde los años
There were three decades of publications. The editors did not limit themselves to studying the most representative artists of the contemporary international scene. Yet, they also collaborated directly with each of them. It should also be highlighted that the magazine was completed with texts on more than 400 artists by a multidisciplinary team of critics, writers, art historians and curators of recognised prestige today.

Given the number of critical essays gathered in each of the magazines, the magazine became a representative library of contemporary art in which artistic collaborations manifested in different ways - on the spines, covers and even inside each one of them. The Faculty of Fine Arts of Cuenca also has a complete collection of these magazines and special editions. In addition, these are available for loan through the library service of the University of Castilla-La Mancha.

\section{Artistic collaborations at Parkett}

The most representative aspect of the creation of the magazin was, without a doubt, the presence of artistic collaborations and the cooperation between publisherartists. This collaboration was so enriching that it led them to create original, signed and numbered editions, which were put up for sale and offered to their subscribers. Thanks to this, they had the possibility of forming a small collection of contemporary art to enjoy at home since most of them had a small format. The Parkett Collection describes itself as "a small museum and a large library of contemporary art" ${ }^{\prime[1]}$. Not all subscribers to the magazine 
ochenta cada una de las ediciones de los diferentes artistas que se ofrecían desde la editorial, pero, afortunadamente Helga de Alvear fue una de ellas, reuniendo cada una de las ediciones que salían a la venta, por ese motivo la Facultad de Bellas Artes de Cuenca cuenta con la colección completa.

Dada la gran cantidad y diversidad de colaboraciones entre diferentes artistas, se configuró en pequeñas ediciones múltiples realizadas en multitud de materiales como: papel, cartón, metal, cristal, barro, cerámica, plástico, poliéster, piedra, látex, aparatos electrónicos y un largo etcétera de combinaciones de materiales. Lo que origina que la colección Parkett sea un ejemplo del desafío que supone la conservación de una colección de arte contemporáneo constituida por una gran complejidad y diversidad de materiales inestables. En este sentido, emplearon elementos de todo tipo desde materiales considerados más tradicionales (Peña 2021), como barro sin cocer (tal como hace el artista Adrian Villar Rojas en la edición para Parkett 93, titulada From the Series Brick Farm, 2013) o el soporte de papel en el que los artistas desarrollan multitud de técnicas de grabado tales como punta seca y aguafuerte empleado por Georg Baselitz para Parkett 11, en Face and Teardrop, 1986 aguatinta a manera que emplea John Currin para Parkett 65 en The Beggar's Alms, 2002 o serigrafía a color como realiza Franz Ackermann con Peak Season, en 2003 para Parkett 68). Hasta materiales más contemporáneos o modernos (no convencionales), tanto los desarrollados por diferentes industrias, como serían por ejemplo los plásticos tal como emplea Jeff Koons en su obra Inflatable Balloon Flower (Yellow),1997 para Parkett 50/51.

Se encuentran multitud de ejemplos sobre el empleo de este material en las ediciones representadas en la colección objeto de estudio, pero en este caso se atenderá a los elastómeros, polímeros naturales o sintéticos con propiedades únicas de deformación.

En lo referente a los plásticos se podrían clasificar, a grandes rasgos, en tres categorías teniendo en cuenta la distribución de entrelazado de las macromoléculas: termoplásticos, termoestables y elastómeros. Estos últimos cuentan con la particularidad de ser muy elásticos pudiendo recuperar su forma una vez deformados. Debido a esta característica, los elastómeros son el material básico de fabricación de otros materiales como la goma, ya sea natural o sintética, y para algunos productos adhesivos. Un elastómero es un compuesto químico formado por miles de moléculas denominadas monómeros que se unen formando enormes cadenas. Por esa propiedad son elásticos ya que son flexibles y se encuentran entrelazadas de manera muy desordenada. Están reticulados en menor extensión y, por ello, se encuentran a temperatura ambiente en estado gomoelástico. En este grupo se hallan las gomas y el caucho, el caucho natural para la obtención del látex y el caucho sintético (derivados del petróleo), ambos materiales muy empleados en la producción artística contemporánea y en la colección Parkett.

El empleo de látex, como materia prima para la fabricación directa de artículos de goma, ofrece ventajas y desventajas respecto a las técnicas de fabricación, la coagulación previa, el secado del caucho coagulado, la preparación y la transformación de las mezclas de caucho sólido con los demás acquired each of the editions of the different artists offered by the publishing house, fortunately Helga de Alvear was one of them, collecting each of the editions that went on sale, which is why the Faculty of Fine Arts in Cuenca has the complete collection.

Given the large number and diversity of collaborations between different artists, the limited editions were made in a multitude of materials such as paper, cardboard, metal, glass, clay, ceramic, plastic, polyester, stone, latex, electronic devices, and a long etcetera of combinations of materials. This diversity makes the Parkett collection an example of the challenge of conserving a complex contemporary art collection with a wide range of unstable materials. In this sense, the artists used elements of all kinds. There are materials considered more traditional (Peña 2021), such as unfired clay, as the artist Adrian Villar Rojas does for the Parkett 93, titled From the Series Brick Farm, 2013. Also paper supports, which artists develop many printmaking techniques such as drypoint and etching, employed by Georg Baselitz (Parkett 11) in Face and Teardrop, 1986; aquatint, used by John Currin for Parkett 65 in The Beggar's Alms, 2002; or color screen printing as done by Franz Ackermann with Peak Season, 2003 (Parkett 68). Even more contemporary or modern (non-conventional) materials developed by different industries, such as plastics as used by Jeff Koons in his work Inflatable Balloon Flower (Yellow), 1997 for Parkett 50/51.

There are many examples of the use of this material in the editions represented in the collection under study. Yet, in this paper, we will focus on elastomers, natural or synthetic polymers with unique deformation properties.

As far as plastics are concerned, they can be broadly classified into three categories - taking into account the interlacing distribution of macromolecules-, those are: thermoplastics, thermosets, and elastomers. The latter, in particular, is very elastic and can recover its shape once deformed. Due to this characteristic, elastomers are the primary material for manufacturing other materials such as natural or synthetic rubber and for some adhesive products. An elastomer is a chemical compound made up of thousands of monomers that join together to form huge chains. Because of this property, they are as elastic as they are flexible and are intertwined in a very disorderly manner. They are cross-linked to a lesser extent and are, therefore, at room temperature in a gomoelastic state. This group includes natural rubber (caoutchouc) for latex and synthetic rubber (derived from petroleum), both of which are widely used in contemporary artistic production and in the Parkett collection.

The use of latex as a raw material for the direct manufacture of rubber products offers advantages and disadvantages concerning manufacturing techniques, previous coagulation, drying of the coagulated rubber, preparation, and transformation of solid rubber mixtures 
ingredientes (Royo 1989: 332). El látex que se obtiene de los árboles de Hevea brasiliensis contiene aproximadamente el 30\% de caucho (Loadman 2005: 22-23). El látex fresco o field latex resulta inestable y se coagula espontáneamente en pocas horas, por lo que para evitarlo se alcaliniza con amoniaco en la propia taza de recolección. Dado que la concentración del látex original no es la adecuada para los procesos de transformación, la primera etapa en la preparación de los tipos comerciales de látex natural es la concentración, para aumentar su contenido de caucho hasta al menos $60 \%$. Existen tres procedimientos de concentración a escala industrial: centrifugación, flotación o cremado y evaporación, pero aproximadamente el 90 por ciento del látex natural concentrado se prepara por centrifugación (Royo 1989: 333).

\section{Caso de estudio}

En el presente caso de estudio se expone el trabajo de investigación realizado sobre una de las obras de la colección, concretamente creada por Susan Rothenberg en el que se muestra la importancia que supone el conocimiento de estos materiales, en este caso de naturaleza inestable para poder establecer unas pautas de conservación preventiva adecuadas sobre cada una de las obras de la colección. Esta artista nació en 1945 en Buffalo, Nueva York y falleció en su residencia en Galisteo, Nuevo México en 2020 a la edad de 75 años. Su trabajo discurrió como pintora, grabadora, escultora y dibujante, consolidándose gracias a sus icónicas imágenes de caballos o ecuestres. Su producción artística ha estado presente en colecciones de museos de todo el mundo, y estuvo representada durante más de treinta años por la galería Sperone Westwater de Nueva York. Además, cabe destacar que fue una de las artistas que representó a los Estados Unidos en la Bienal de Venecia de 1980. La edición elaborada en 1995 por la artista para Parkett 43 recibe el título de Bear Skin Rug. Se trata de una edición de setenta ejemplares fabricada aparentemente en látex sintético como pueden ver en la web de la propia editorial [Figura 3]. with otheringredients (Royo 1989:332).The latex obtained from Hevea brasiliensis trees contains approximately 30\% rubber (Loadman 2005: 22-23). The fresh latex or field latex is unstable and coagulates spontaneously in a few hours, so to avoid this, it is alkalized with ammonia in the collection cup itself. Since the concentration of the original latex is not suitable for the transformation processes, the first step in preparing commercial types of natural latex is increasing the concentration of rubber content to at least $60 \%$. In regards to this, there are three concentration procedures on an industrial scale: centrifugation, flotation or creaming and evaporation, but approximately $90 \%$ of the concentrated natural latex is prepared by centrifugation (Royo 1989: 333).

\section{Case study}

This case study presents the research work carried out on one of the artworks in the collection, created explicitly by Susan Rothenberg, which shows the importance of knowing these unstable nature materials in order to establish appropriate preventive conservation guidelines for each of the artworks in the collection. Rothenberg was born in 1945 in Buffalo, New York, and died at her residence in Galisteo, New Mexico in 2020. She worked as a painter, printmaker, sculptor and draftswoman, establishing herself through her iconic images of horses and equestrians. Her artistic production has been present in museum collections worldwide, and she was represented for more than thirty years by the Sperone Westwater Gallery in New York. She was also one of the artists who represented the United States at the 1980 Venice Biennale. The edition produced in 1995 by the artist for Parkett 43 is called Bear Skin Rug. It is an edition of seventy copies apparently made of synthetic latex, as presented on the publisher website [Figure 3].

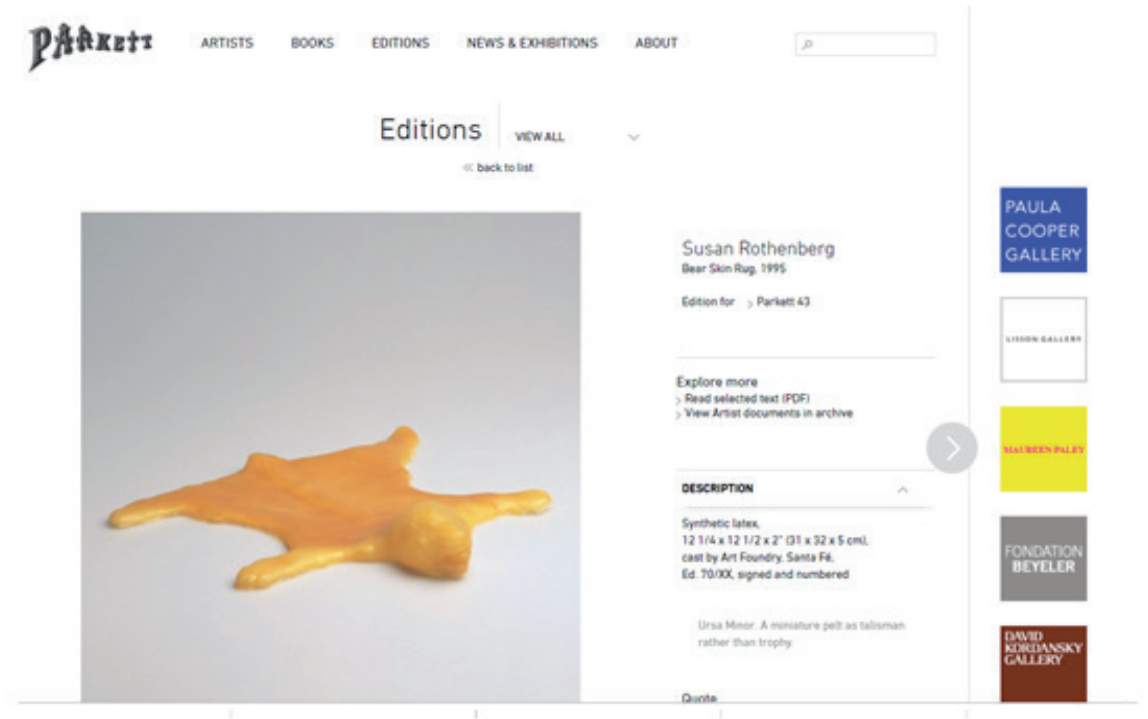

Figura/Figure 3.- Captura de pantalla de la edición Bear Skin Rug de Susan Rothenberg de la página web de la revista Parkett (captura de pantalla:17/03/2020). / Screenshot of Susan Rothenberg's Bear Skin Rug issue from the Parkett magazine website (screenshot: 03/17/2020). 
Se debe señalar que, en una colección de este tipo, con una importante carga conceptual, resulta indispensable tener en cuenta toda la información disponible sobre la artista, ya sea en forma de entrevistas (Simon 1995) o los documentos existentes relacionados con la obra en cuestión ya que en muchas ocasiones se trata de explicaciones técnicas o planos que realiza el propio artista sobre cómo debe manipularse o instalarse su obra. Por tanto, como complemento a la obra de Susan Rothenberg, resulta de interés destacar los documentos de archivo de la propia editorial, como es el fax que envió en su momento la artista a la editorial con algunas especificaciones y aclaraciones relativas a la edición. El fax está registrado el día 7 de marzo de 1995 (se trata de un mero testimonio de que las actividades de Parkett se acontecían en dos partes del mundo diferentes y eso lleva a la discrepancia de fechas ya que la artista se encontraba en un huso horario americano y el receptor en un huso horario europeo), y en él se describe, básicamente, cómo se debía fotografiar, algunas especificaciones sobre el propio objeto, así como el título definitivo traducido como Alfombra de piel de oso y consideraciones sobre el número de ediciones [Figura 4].
For a collection of this type, with a critical conceptual load, it is essential to consider all the available information about the artist, whether in the form of interviews (Simon 1995) or existing documents related to the work in question. On many occasions, we find that these documents are technical explanations or plans made by the artist herself on how her work should be handled or installed. Therefore, as a complement to Susan Rothenberg's artwork, the archival documents play an important role for us. A particular example of this is the fax that the artist sent to the publisher (figure 4), with some specifications and clarifications regarding the edition. The fax is registered on March 7, 1995 (this is a mere testimony that Parkett's activities took place in two different parts of the world, and that leads to the discrepancy of dates since the artist was in the American time zone and the receiver in the European time zone), and it basically describes how it was to be photographed, some specifications about the object itself, as well as the final title translated as Bear Skin Rug and considerations about the number of editions [Figura 4].

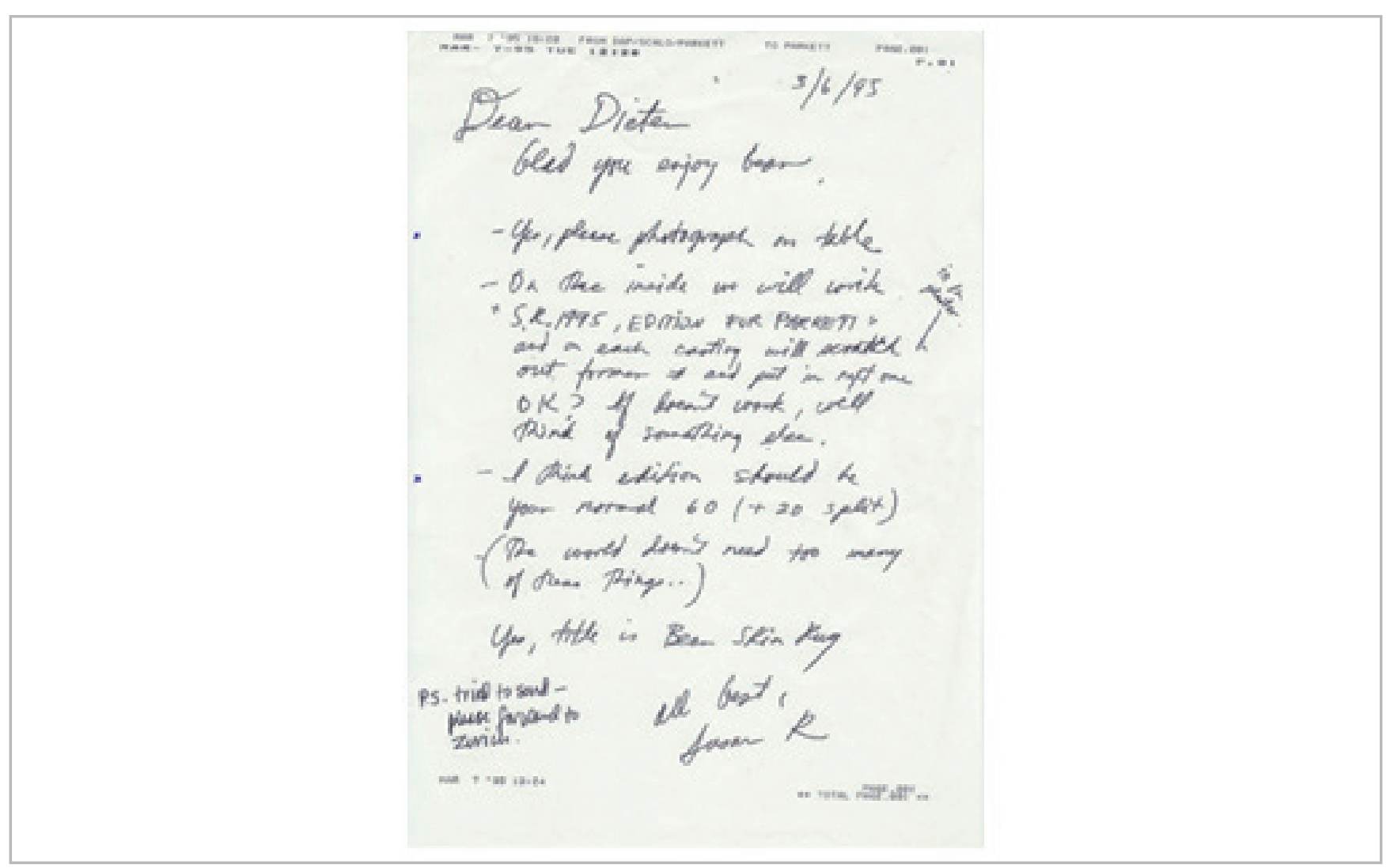

Figura/Figure 4.- Documentos de Archivo de Parkett de la edición de Susan Rothenberg (Fax enviado por la artista a la editorial mediante una carta fechada el 6 de marzo de 1995 y recibido el 7 de marzo de 1995 a las 13:24 h). / Parkett's archival documents of the Susan Rothenberg edition. (Fax sent by the artist to the publisher by letter dated March 6, 1995, and received March 7, 1995 at 13:24 h.).

La evaluación y revisión del estado de conservación de las colecciones artísticas resulta importante, pero, en colecciones de arte contemporáneo, puede resultar, en determinadas ocasiones, indispensable un control más exhaustivo y continuo en el tiempo. Se podría pensar que al ser producciones recientes no es tan necesario o importante, pero justamente las evidencias demuestran lo contrario.
Evaluating and revising the condition of art collections are essential aspects in conservation, but, in contemporary art collections, more exhaustive and continuous control over time may be indispensable on certain occasions. Since these are recent productions, one might think it is unnecessary or essential, but the evidence shows the opposite. 
En este caso, especialmente, las revisiones han sido periódicas en lo que respecta a la edición 24/70 de Susan Rothenberg, ya que ha sido objeto de préstamo por diferentes instituciones. La última de ellas para una muestra titulada Unique multiples: teaching with the Parkett collection from UCLM ${ }^{[2]}$, en Estados Unidos a finales del 2019, concretamente con motivo de la exposición realizada en la Mary Porter Sesnon Art Gallery de la Universidad Santa Cruz, California. Esta muestra fue comisariada por Enrique H. Martínez Leal y Shelvy Graham y en la que la autora de este artículo tuvo la oportunidad de realizar las tareas de correo de la misma. Gracias a este papel, se pudo realizar un monitorizado de temperatura y humedad relativa individualizado durante todo el recorrido de la obra, incluyendo el transporte transatlántico, y el tiempo de duración de la exposición mediante mini data loggers testo 175. Este tipo de dispositivos permite realizar mediciones y documentar la temperatura y humedad relativa en espacios cerrados gracias al sensor de humedad externo garantizando la seguridad de los datos y obteniendo datos fiables al estar basados en la tecnología de medición más moderna. Permite su programación y descarga de datos mediante un software ComSoft Profesional[3]. Por dicho motivo, uno de estos dispositivos se dispuso junto a la obra en cuestión programado para realizar mediciones cada hora desde su embalaje en la sede de Cuenca realizado por la empresa SIT y transporte hasta su recepción en la Mary Porter Sesnon Art Gallery de la Universidad Santa Cruz, California. Posteriormente se mantuvo en la vitrina junto a la obra la duración y el tiempo de exposición de la muestra y una vez concluida se realizó exactamente el mismo procedimiento hasta que llegó a la sede de Cuenca.

Se considera importante destacar, además, que, en dicha edición fabricada aparentemente con látex sintético según señala la propia editorial, no se han observado irregularidades significativas en los últimos siete años de revisiones periódicas realizadas sobre su estado de conservación. Cabe subrayar que ha sido objeto de estudios colorimétricos además de monitorización regular. Como herramienta para la descripción del color se usó el colorímetro Konica Minolta Sensing Chroma Meter modelo CR-410, que permitió extraer registros de color en diferentes modalidades. Las medidas se expresaron en coordenadas CIE Lab que corresponden a los promedios de, al menos, cinco medidas tomadas todas ellas con un patrón preestablecido [Figura 5].

El elemento de estudio es un objeto artístico fabricado con polímeros, concretamente confeccionado con elastómeros de caucho, por lo que se debe recalcar que el látex es uno de los materiales con más riesgo de deterioro de la colección, pues como define Royo (Royo 1989: 180) "el látex es la primera forma en que se obtienen tanto el caucho natural como los cauchos sintéticos preparados por polimerización en emulsión, que representan la mayor parte del volumen total de caucho sintético producido" (1989: 180).

A pesar de poder comprobar que el estado de conservación es, aparentemente, estable tanto a nivel colorimétrico como realizando un examen bajo binocular, se puede afirmar que es bueno, pero a pesar de ello se debería tener presente la propia problemática del material en otras colecciones artísticas, así como diferentes
In Susan Rothenberg's 24/70 edition case, revisions have been periodic concerning, which has been on loan from different institutions. The last one for an exhibition entitled Unique multiples: teaching with the Parkett collection from UCLM ${ }^{[2]}$ in the United States, at the end of 2019. This was specifically for the exhibition held at the Mary Porter Sesnon Art Gallery at Santa Cruz University, California. The exhibition was curated by Enrique $\mathrm{H}$. Martínez Leal and Shelvy Graham, and in which the author of this paper had the opportunity to work as the courier of the piece. Thanks to this role, individualized monitoring of temperature and relative humidity was carried out throughout the exhibition, including the transatlantic transport and the exhibition's duration, using mini data loggers testo 175 . This type of device allows measurements and documentation of temperature and relative humidity in closed spaces thanks to the external humidity sensor, guaranteeing data security and obtaining reliable data based on modern measurement technology. It can be programmed and downloaded using ComSoft Professional software ${ }^{[3]}$. For this reason, one of these devices was placed next to the artwork and programmed to take measurements every hour from the time it was packed at the Cuenca headquarters by SIT, and transported to its reception at the Mary Porter Sesnon Art Gallery at Santa Cruz University, California. Subsequently, it was kept in the showcase next to the artwork for the duration of the exhibition and once it was finished, the same procedure was carried out until it returned to Cuenca.

It is also important to point out that, according to the publisher, no significant irregularities have been observed in this edition during the last seven years of periodical condition checks carried out. It should be noted that it has been the object of colorimetric studies as well as regular monitoring. A Konica Minolta Sensing Chroma Meter model CR-410 colorimeter was used as a tool for color description, which made it possible to extract color records in different modalities. The measurements were expressed in CIE Lab coordinates that correspond to the averages of at least five measurements, all of which were taken with a pre-established pattern [Figure 5].

As the element of the study is an artistic object made of polymers, made explicitly with rubber elastomers, it should be emphasized that latex is one of the materials with more risk of deterioration at the collection. As defined by Royo, "latex is the first form in which both natural rubber and synthetic rubbers prepared by emulsion polymerization are obtained, which represent most of the total volume of synthetic rubber produced" (1989: 180).

Despite verifying that the conservation condition of this piece is stable, both colorimetrically and under binocular examination, the material issues in other art collections should be considered, as well as different studies conducted by many professionals in the field 
estudios realizados por muchos profesionales en la materia (Shashoua 2008; Madden y Learner 2014). Por dicho motivo se han realizado diferentes estudios, como se expone a continuación, además de fotogrametría (Peña 2017), un seguimiento fotográfico comparativo con ColorChecket, seguimiento de temperatura y humedad relativa, ensayo microclimático a largo plazo, ensayos de envejecimiento acelerado con probetas experimentales y estudios colorimétricos ${ }^{[4]}$. Se considera que, en materiales de este tipo, sería deseable conocer exactamente su composición, pero se debe apuntar y reconocer que en ocasiones resulta complicado dar con los investigadores adecuados para poder analizar la composición de esta variedad de materiales.

El grupo de Investigación de elastómeros del Departamento de Física de Polímeros, Elastómeros y Aplicación Energéticas
(Shashoua 2008; Madden and Learner 2014). For this reason, additional analysis were carried out, such: photogrammetry (Peña 2017), comparative photographic monitoring with ColorChecket, environmental monitoring (temperature and relative humidity), longterm microclimatic testing, accelerated aging tests with experimental specimens, and colorimetric analysis ${ }^{[4]}$. In cases like this, it is always desirable to identify the precise composition of the materials used in the artwork. However, sometimes it is difficult to find the right researchers to analyse the composition of this variety of materials.

Thankfully, the elastomers research group of the Department of Polymer Physics, Elastomers and Energy

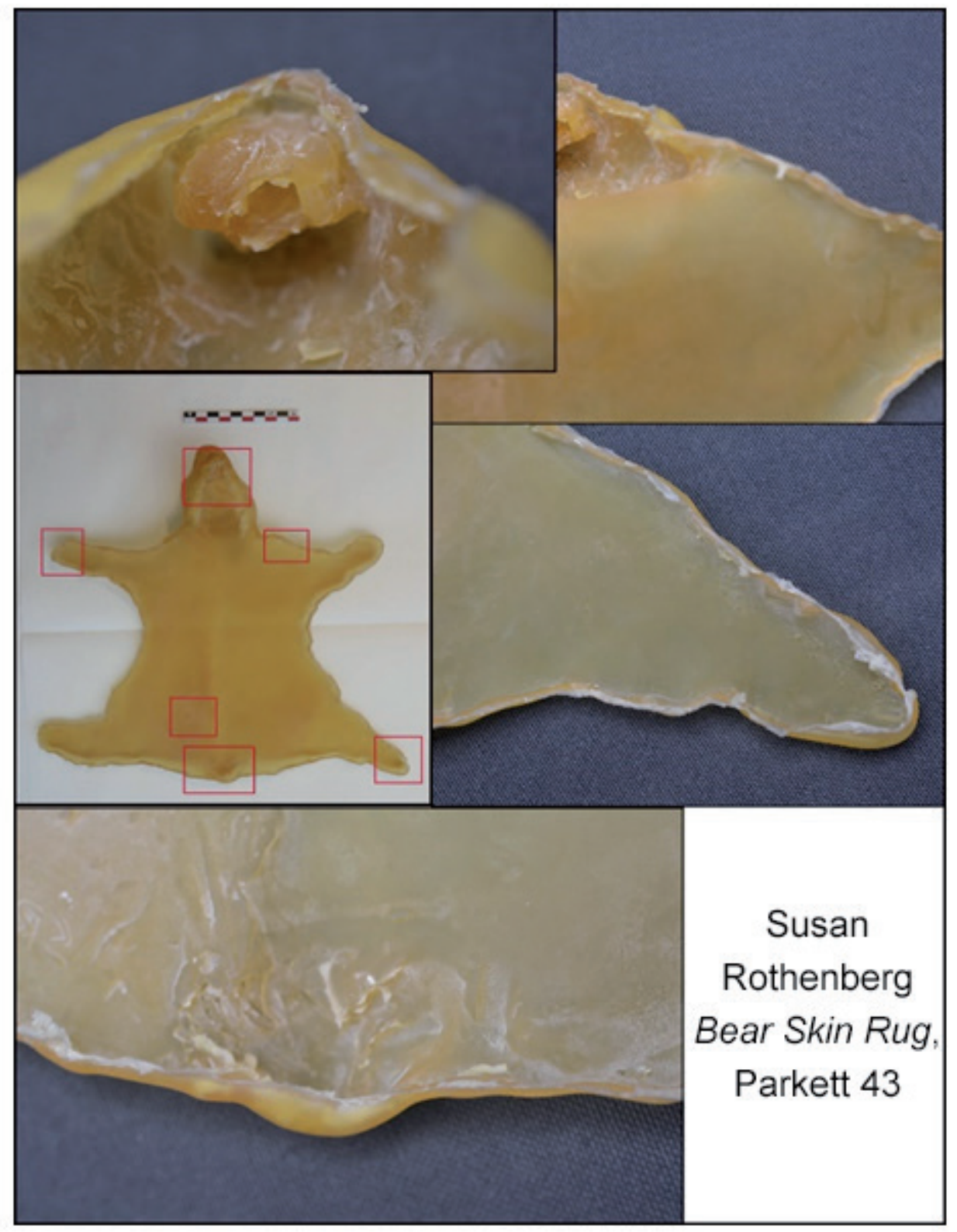

Figura/Figure 5.- Documentación fotográfica extraída del informe de conservación personal de la autora del artículo, donde se incluye en el apartado fotográfico detalles de la vista posterior de la edición de Susan Rothenberg para Parkett 43. Detalles de las tomas de medición colorimétricas. / Photographic documentation extracted from the personal conservation report of the author of the article, where details of the rear view of Susan Rothenberg's edition of Parkett 43 are included in the photographic section. Details of the colorimetric measurements 
del Instituto de Ciencia y Tecnología de Polímeros de la Agencia Estatal del Consejo Superior de Investigaciones Científicas (CSIC), está compuesto por Juan López Valentín, responsable del Grupo de Investigación de elastómeros del Centro de Química Orgánica, Manuel Lora Tamayo y el técnico Alberto Fernández Torres, del Instituto de Ciencia y Tecnología de Polímeros, entre otros ${ }^{[5]}$. Fueron los encargados de realizar dichos análisis, ya que cuentan con décadas de investigación en el campo, lo que los ha llevado a disponer de una amplia espectroteca especializada en elastómeros.

Para conocer la composición exacta del material resultaba necesario someter a un análisis del espectro infrarrojo, por lo que requirió de una micromuestra de $1 \mathrm{~mm}$ que fue extraída de la parte posterior y trasera de la edición 24/70 de Bear Skin Rug. El equipo empleado fue FT-IR Spectometer-marca Perkin Elmer. El proceso de análisis consistió en que la muestra pase por el espectro de selenio de zinc y diamante y el haz de luz penetre una micra sobre la micromuestra y lo devuelva atenuado para hacer la lectura de la capa exterior. En este caso en concreto, el técnico Alberto Fernández Torres, del Instituto de Ciencia y Tecnología de Polímeros del CSIC empleó para su análisis el accesorio ATR Sampling, para conseguir una reflexión atenuada debido a las micras de la muestra.

El procesador de datos, a través del sofware Spectrum, traduce en forma gráfica las lecturas de las vibraciones en diferentes espectros con números determinados que corresponden a diversos grupos (834,91, grupos vinilos, 1661,88, grupos carbonilo, etc.), como se evidencia en la siguiente gráfica [Figura 6].
Applications of the Institute of Polymer Science and Technology of the State Agency of the Spanish National Research Council (CSIC) performed the analyses in this case. The group is composed of Juan López Valentín, head of the elastomers research group of the Organic Chemistry Center, Manuel Lora Tamayo and technician Alberto Fernández Torres, from the Institute of Polymer Science and Technology, among others ${ }^{[5]}$. Their decades of research in the field led them to have an extensive spectro-library specialized in elastomers that helped in our research.

To identify the material's exact composition, it was necessary to submit it to an analysis of the infrared spectrum, which required a $1 \mathrm{~mm}$ microsample that was extracted from the back and rear of the 24/70 edition of Bear Skin Rug. The equipment used was a Perkin Elmer FT-IR Spectrometer. The analysis process consisted of the sample passing through the zinc-diamond selenium spectrum and the light beam penetrating one micron over the microsample and returning it attenuated to make the reading of the outer layer. In this particular case, the technician Alberto Fernández Torres, used the ATR Sampling accessory for his analysis to achieve an attenuated reflection due to the microns of the sample.

Through the Spectrum software, the data processor graphically translated the vibration readings into different spectra with specific numbers corresponding to different groups (834.91, vinyl groups, 1661.88, carbonyl groups, etc.), as shown in the following graph [Figure 6].

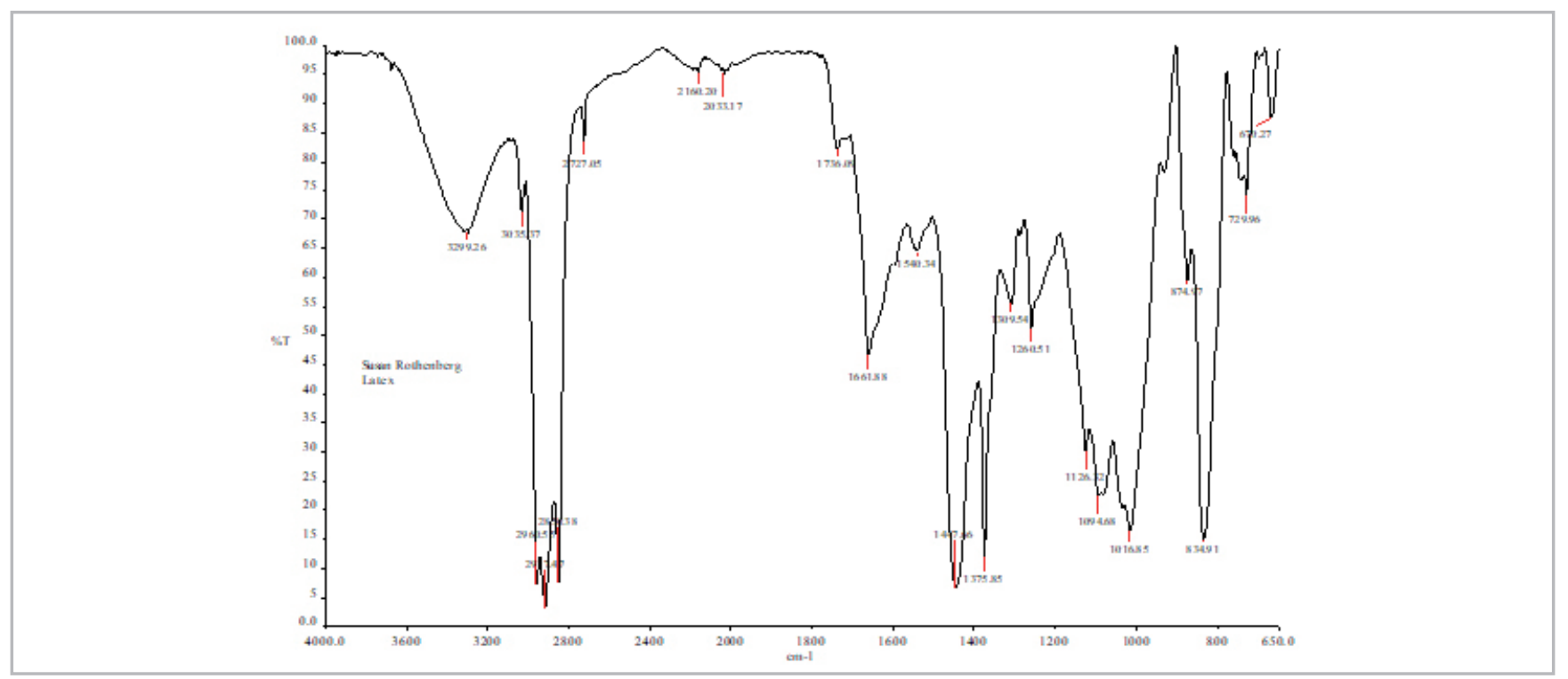

Figura/Figure 6.- La gráfica manifiesta las vibraciones del espectro infrarrojo realizada a la micromuestra tomada de la obra de Susan Rothenberg (realizada por Grupo de elastómeros del CSIC). / The graph shows the vibrations of the infrared spectrum of the micro-sample taken from the work of Susan Rothenberg (made by the Elastomers Group of CSIC).

A partir de aquí, la metodología de trabajo, simplificando su explicación a nivel técnico, consistió en realizar la comparación con otras muestras de elastómeros existentes en la espectroteca para comprobar si existía correspondencia con cada uno de los componentes y determinar su naturaleza. En este caso en
Simplifying its explanation at a technical level, the work methodology consisted of comparing other samples of existing elastomers in the spectrophotometer library and checking if there was a correspondence with each of the components and to determine their nature. In 
concreto interesaba conocer si se trataba de caucho natural o sintético, por lo que se procedió a buscar la gráfica de caucho natural en la espectroteca, concretamente natural rubber NR 5 CV 60. En la siguiente gráfica [Figura 7] se puede observar el solapamiento de ambas vibraciones, la representada en color negro correspondiente a la micromuestra de la obra de Susan Rothenberg, mientras que la de color azul es una muestra de caucho natural de la espectroteca. Al comparar los diferentes grupos que componen el material, se pone de manifiesto que ambos materiales son elastómeros de caucho natural, es decir, látex de origen natural. Por tanto, los estudios de espectro infrarrojo revelan que la obra de Susan Rothenberg está confeccionada sin lugar a duda con látex natural y no látex sintético como figura en todos los datos facilitados por la editorial, señalados al inicio del presente artículo. this particular case, it was interesting to see whether it was natural or synthetic rubber, so we looked for the natural rubber graph in the spectrophotometer library, specifically natural rubber NR 5 CV 60. In the following diagram [Figure 7], the overlap of both vibrations can be observed, the one represented in a black color corresponding to the micro-sample of Susan Rothenberg's artwork, while the one in blue color is a sample of natural rubber from the spectroteca. By comparing the different groups that make up the material, it becomes clear that both materials are natural rubber elastomers: latex of natural origin. Therefore, the infrared spectrum studies reveal that Susan Rothenberg's artwork was undoubtedly made with natural latex and not synthetic latex, as it appeared in all the data provided by the publisher.

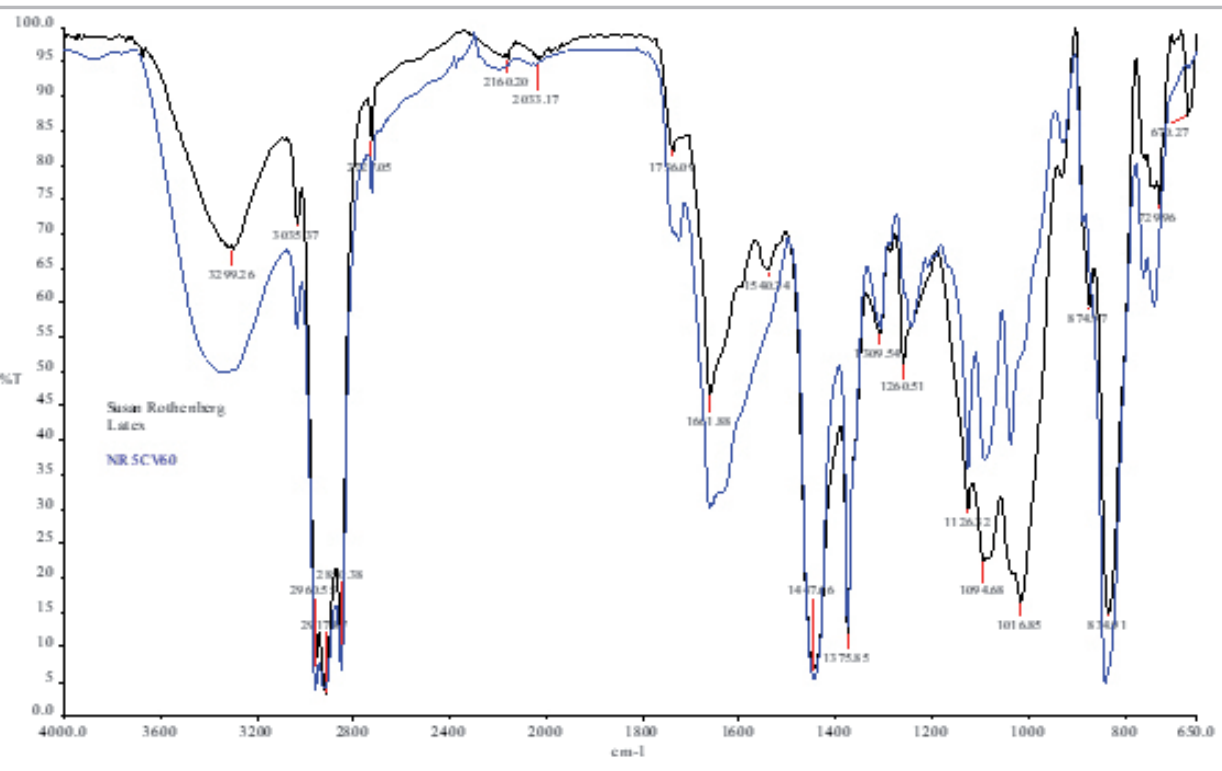

Figura/Figure 7.- La gráfica manifiesta las vibraciones del espectro infrarrojo realizada a la micromuestra de látex de la obra de Susan Rothenberg en color negro y representada en color azul la muestra de la espectroteca correspondiente a NR 5CV 60, un caucho natural. (Realizada por Grupo de elastómeros del CSIC). / The graph shows the vibrations of the infrared spectrum of the latex microsample of Susan Rothenberg's work in black and the spectrophotometer sample corresponding to NR 5CV 60, a natural rubber, represented in blue. (Carried out by the Elastomers Group of CSIC).

Como parte de un estudio de investigación más amplio relacionado con el plan de conservación preventiva de la colección Parkett, se siguieron modelos de especialistas como Odile Madden, conservadora del Getty Conservation Institute de Los Ángeles y especializada en materiales plásticos (Madden y Learner, 2014) o Stefan Michalski, especializado en conservación preventiva (Michalski 2018). Por ese motivo, se estudiaron los parámetros de temperatura y humedad relativa de sala expositiva y almacén, así como los factores de riesgo y una vez analizados, se realizaron probetas experimentales de ciertas obras de la colección. Posteriormente se pudo analizar el comportamiento de los materiales de la colección a corto, medio y largo plazo, realizando ensayos climáticos simulando las condiciones ambientales en un periodo de tiempo y observando el deterioro originado. No es objeto de este artículo exponer dichos casos de estudio, pero se considera relevante hacer mención sobre la elección del objeto artístico de Susan Rothenberg ya que se debe a la propia composición
As part of a broader research study related to the preventive conservation plan of the Parkett collection, other specialist models were followed. Those were Odile Madden's model (Madden and Learner, 2014), conservator at the Getty Conservation Institute in Los Angeles and specialized in plastic materials, and Stefan Michalski's model (Michalski 2018), specialized in preventive conservation. For this reason, the temperature and relative humidity parameters of the exhibition room and storage room were studied and the risk factors. Once analysed, experimental mockups were made based on specific artworks from the collection. Subsequently, it was possible to analyse the behavior of the collection's materials in the short, medium and long term, carrying out climatic tests simulating environmental conditions over a period of time and observing the deterioration caused. It is not the purpose of this paper to present these case studies. Yet, it is considered relevant to mention the 
material con el que está confeccionado. Por ello, se realizaron probetas experimentales con el mismo tipo de material en el que estaba materializada Bear Skin Rug, y se sometieron a ensayo climático. Una de las intenciones que se perseguía con el presente análisis era identificar la realidad material de la obra para no dar lugar a equívocos que podían haber surgido si no se hubiera realizado un espectro infrarrojo de la obra original.

\section{Conclusiones}

Se pueden extraer varias conclusiones de partida simplemente por insistir en realizar el análisis del espectro infrarrojo, resultando realmente útil por varios motivos:

En primer lugar, se hace necesario conocer la composición real del material de cara a su estudio y preservación. A pesar de referirse a elastómeros de caucho, tanto en lo citado en los documentos de archivo por parte de la editorial, como en lo encontrado gracias a los resultados, cabe destacar importantes diferencias entre ambos. La estabilidad de uno y de otro es claramente diferente ya que en términos generales es mucho más inestable el caucho natural que el caucho sintético.

En segundo lugar, el poder verificar el material empleado en una obra de la colección en la que se asumió que estaba compuesta por otro tipo de material. Este hecho reafirma una cuestión importante en lo que respecta a los materiales de arte contemporáneo. En muchas ocasiones, tanto el artista como, en este caso, la propia editorial que encarga la realización de las ediciones a Art Foundry, Santa Fé, desconocen los materiales concretos con los que están confeccionadas las ediciones. Asimismo, no debemos olvidar que, al tratarse de una edición con setenta ejemplares, existen diferentes propietarios que tienen una idea errónea sobre la propia composición de la edición Bear Skin Rug. Además, llegados a este punto y dada la tirada de la edición, sería aconsejable confirmar que todas las ediciones fueron realizadas con el mismo material, por lo que sería conveniente sugerir la necesidad de un análisis previo.

En tercer lugar, cabe destacar que otro de los objetivos que se perseguía, en un estudio más amplio y con el análisis, consistía en fabricar probetas experimentales con el mismo material en el que estaba confeccionada la obra de Susan Rothenberg para someter a ensayo climático. El análisis de espectro infrarrojo ha sido claramente determinante, porque si se hubiese corroborado la composición que dictaminaba la editorial, se hubiese partido de un supuesto erróneo. En este punto se ha de resaltar que, antes de realizar análisis, previamente fueron realizadas diversas pruebas con látex sintético para obtener probetas experimentales $y$, dado que no ofrecían el mismo aspecto, éste fue uno de los indicativos para sospechar de la composición de dicho objeto artístico.

Para finalizar, se ha de precisar que a esta pieza se le ha otorgado un nivel de riesgo alto en la colección una vez estudiadas otro tipo de piezas en la misma, compuestas por materiales más estables $y$, por tanto, en lo que respecta a su control de temperatura y research developed from Susan Rothenberg's artistic object. Experimental specimens were produced with the same type of material in which Bear Skin Rug and those were subjected to climatic testing. One of the intentions pursued with the present analysis was to identify the real composition of the material, which would have occurred if we had not carried out an infrared spectrum of the original work.

\section{Conclusions}

Several conclusions can be drawn simply thanks to the analysis of the infrared spectrum, which was greatly helpful for several reasons:

Firstly, it became necessary to identify the accurate composition of the material with a view to its study and preservation. Despite being referred to as rubber elastomers, both in the archival documents and on publisher website, the results showed differently. The differences between the two are worth noting for their conservation/stability as, in general terms, natural rubber is much more unstable than synthetic rubber.

Secondly, verifying the material used in an artwork of the collection - specially when it was wrongly assumed to be composed of another type of material. This fact reaffirms an essential issue regarding contemporary art materials. On many occasions, both the artist and (in this case) the publishing house that commissioned the editions were unaware of the specific materials with which the editions were made. Likewise, we must not forget that, since this is an edition with seventy copies, different owners could have a wrong idea about the composition of the Bear Skin Rug edition. At this point, and given the print run of the edition, it would be advisable to confirm that all the editions were made with the same material, so it would be convenient to suggest the need to analyse the other pieces.

Thirdly, notice that another aim, in a broader study and with the analysis, was to manufacture experimental mockups with the same material as Susan Rothenberg's artwork, in order to perform climatic testing. The infrared spectrum analysis was decisive because if the composition had been corroborated as the one stated by the publisher, it would have been based on an erroneous assumption. It should be noted that, before the analysis, several tests were previously carried out with synthetic latex to obtain experimental specimens and, since they did not have the same appearance, this was one of the indications to suspect the composition of this art object.

Finally, this piece has been given a high-risk level in the collection after studying other types of works in it, composed of more stable materials. Therefore, with regard to its temperature and relative humidity control, it 
humedad relativa, se aconseja controlar los parámetros climáticos, especialmente la temperatura, ya que tiende a degradarse con temperaturas elevadas; debido a un proceso termo-oxidativo, su estructura química se rompe, perdiendo propiedades y con tendencia al amarillamiento de la obra.

Hay que tener presente que existe una dificultad para conservar inalteradas este tipo de obras, en muchos casos resulta complejo de mantener, especialmente cuando la colección pertenece a una universidad pública y no se cuenta con los recursos que podría tener, por ejemplo, un museo. Un adecuado acondicionamiento ambiental, eliminación completa de luz ultravioleta, almacenamiento adecuado con la construcción de embalajes específicos confeccionados para cada una de las obras como estrategia de almacenaje, son las medidas básicas de conservación preventiva que se sugieren y se están aplicando.

Por tanto, se recomienda mantener la obra a temperaturas preferiblemente bajas, teniendo en cuenta el tipo de obras que se encuentran en este ámbito, y valorando los resultados obtenidos de los ensayos microclimáticos a largo plazo para la conservación de la colección (Peña y Pérez 2021). Y, dado que las concentraciones elevadas de oxígeno no le favorecen, el tiempo que no se encuentre expuesta es preferible conservarla en una caja de polietileno testado, preferiblemente fabricado para obras de arte. Pero se podría recomendar al resto de coleccionistas que posean algunas de las ediciones, en caso extremo, hacer uso de una caja de polietileno para uso alimentario - siempre que su testeo sea semejante a los realizados para obras de arte- ya que de esta forma se garantiza que el material del envase se haya testado y es menos probable que se produzcan migraciones de otros componentes a la obra. Son recomendaciones que parten de un estudio concreto de dicha edición, pero que podrían resultar de interés a diferentes coleccionistas y particulares que poseen algún ejemplar de la misma.

A pesar de estos consejos, resulta esencial seguir realizando seguimientos de conservación periódicos. En este punto se debe puntualizar que el estudio de la fotogrametría ha sido realmente importante, fundamentalmente para poder llevar un control de la pieza a corto y medio plazo, especialmente de cara a las exposiciones temporales realizadas durante los últimos años. Uno de los factores de riesgo es el transporte de objetos artísticos por lo que requiere una metodología planificada dependiendo de las exigencias de cada una de las piezas de la colección, por lo que hay que recalcar una vez más la importancia del conservador durante todo el proceso de préstamo. Indudablemente, el haber realizado un estudio de conservación completo de la colección, facilita para conocer la fragilidad de un objeto artístico ya que no solo depende del propio material del que esté conformado, sino de su estado de conservación, puntos débiles, etc., por ello se considera que la figura de correo resulta indispensable.

Por todo ello, se concluye, señalando una vez más, la importancia de intentar conocer los materiales concretos de una obra de arte contemporáneo puesto que resultará esencial para realizar estudios completos de documentación y/o colección, y de esta forma poder garantizar una adecuada conservación de la misma y un plan de conservación preventiva. is advisable to control the climatic parameters, especially the temperature, as latex tends to degrade at high temperatures, and due to a thermo-oxidative process, its chemical structure breaks down, losing properties and yellowing.

It must be kept in mind that there is a difficulty in preserving this type of artworks unaltered. In many cases, it is complex to maintain, especially when the collection belongs to a public university and does not have the resources that, for example, a museum could have. For instance, adequate environmental control, complete elimination of ultraviolet light, good storage, and specific packaging construction made for each work as a storage strategy. These are the primary preventive conservation measures that were suggested and are being applied.

In conclusion, it is recommended to keep Rothenberg's artwork preferably at low temperatures, considering the type of works found in this area, and evaluating the results obtained from long-term microclimatic tests for the conservation of the collection (Peña and Pérez 2021). Given that high concentrations of oxygen do not favor this material, it is preferable to keep it in a tested polyethylene box, preferably made for works of art, during the time it is not displayed. However, it could be recommended to other collectors who own some of the editions, in extreme cases, to use a polyethylene box (like a food use box) —if tests results are similar to those carried out for works of art- since in this way it is guaranteed that the packaging material is less likely to migrate components to the artwork. These recommendations are based on a specific study of the artwork at The Parkett Collection but could be of interest to different collectors and individuals who own a copy of this edition.

Despite this advice, it is still essential to continue to carry out periodic conservation checks. At this point, the study of photogrammetry has been critical, mainly to keep track of the piece in the short and medium term, especially given the temporary exhibitions held in recent years. One of the risk factors is the transport of art objects, as it requires a planned methodology depending on the requirements of each piece in the collection. So, we must once again emphasize the importance of the conservator throughout the loan process. Undoubtedly, having carried out a complete conservation study of the collection makes it easier to know the fragility of an artistic object since it depends not only on the material itself but also on its conservation condition, which is why it is considered that the figure of the conservator is indispensable.

Therefore, it is concluded, pointing out the importance of knowing the specific materials of a contemporary artwork since it will be essential to carry out complete studies of documentation and/or collection, and thus to ensure proper conservation of the same and a preventive conservation plan. 


\section{Notas}

[1] La expresión descrita por Parkett como "a small museum and a large library on contemporary art" podemos encontrar tanto en las publicaciones de las revistas como en su página web https://www. parkettart.com/ [Consulta: 16/08/2021].

[2] The Mary Porter Sesnon Art Gallery at the University of California, Santa Cruz: https://art.ucsc.edu/sesnon/unique-multiplesteaching-parkett-collection [Consulta: 16/02/2021].

[3] https://www.testo.com/es [Consulta: 10/08/2021]

[4] Estos datos forman parte de un estudio más extenso recogido en la tesis doctoral, titulada La conservación preventiva en la Colección Parkett de la facultad de Bellas Artes de Cuenca. Importancia de la documentación en la conservación contemporánea, realizada por la autora del artículo bajo la dirección del catedrático Dr. Vicente Jarque.

[5] Grupo de elastómeros: http://www.elastomeros.ictp.csic.es [Consulta: 27/10/2020].

\section{Notes}

[1] The expression described by Parkett as "a small museum and a large library on contemporary art" can be found both in magazine publications and on his website https://www.parkettart.com/ [Accessed: 08/16/2021].

[2] The Mary Porter Sesnon Art Gallery at the University of California, Santa Cruz: https://art.ucsc.edu/sesnon/unique-multiplesteaching-parkett-collection [Accessed: 16/02/2021

[3] https://www.testo.com/es [Accessed: 10/08/2021].

[4] This data is part of a more extensive study contained in the doctoral thesis entitled La conservación preventiva en la Colección Parkett de la facultad de Bellas Artes de Cuenca. La importancia de la documentación en conservación de arte contemporáneo, carried out by the author of the article under the direction of Dr. Vicente Jarque.

[5] Elastomers group: http://www.elastomeros.ictp.csic.es [Accessed: 27/10/2020].

\section{Referencias / References}

LOADMAN, J. (2005). Tears of the tree. The story of rubber. A modern marvel. Oxford University Press on Demand.

MADDEN, O. y LEARNER, T. (2014). "Preserving plastics. An evolving material, a maturing profession". Conservation perspectives. Conservation of plastics. The Getty Conservation Institute, 29 (1).

MICHALSKI, S. (2018). "Sharing Conservation Decisions: Tools, Tactics, and Ideas". Sharing Conservation Decisons: Current Issues and Future Strategies, Rome: ICCROM, 183-202.

PEÑA, C. (2021). "Sistema de gestión y conservación preventiva de la colección Parkett de la Facultad de Bellas Artes de Cuenca (España)" En actas ENAC 2020, Encuentro Nacional sobre Registro, Documentación y Conservación de Arte Contemporáneo, Argentina.

PEÑA, C. (2017). "Los avances de la fotogrametría aplicada a la conservación de las obras de la colección Parkett". Jornadas Doctorales Vicerrectorado Investigación de la Universidad Castilla La Mancha, Albacete: Universidad Castilla La Mancha, 62-63.

PEÑA C. y PEREZ V. (2021). "Ensayo microclimático a largo plazo para la conservación de la colección Parkett”. En Congreso Ciencia y Arte VIII. Ciencias y tecnologías aplicadas a la conservación del patrimonio. Subdirección General del Instituto del Patrimonio Cultural de España.

ROYO, J. (1989). Manual de tecnología del caucho. Consorcio Nacional de Industriales del Caucho, Ciencia y Tecnología de materiales poliméricos (Vol. I), Madrid: Instituto de Ciencia y Tecnología de Polímeros (CSIC).

SHASHOUA, Y. (2008). Conservation of Plastics: Materials Science, Degradation and Preservation, Oxford: Butterworth-Heinemann.

SIMON, J. (1995). “On Walking and Working. An Interview with Susan Rothenberg by Joan Simon". Parkett 43: 90-103

ROTHENBERG, S. (1995). "Alfombra de piel de oso". Parkett, 45 https://www.parkettart.com/editions/43-edition-rothenberg.html. [Consulta: $22 / 01 / 2021]$

The Mary Porter Sesnon Art Gallery at the University of California, Santa Cruz: https://art.ucsc.edu/sesnon/unique-multiples-teachingparkett-collection [Consulta: 16/02/2021].

Grupo de elastómeros del CSIC: http://www.elastomeros.ictp.csic.es [Consulta: 27/10/2020]. 


\section{Autor/es}

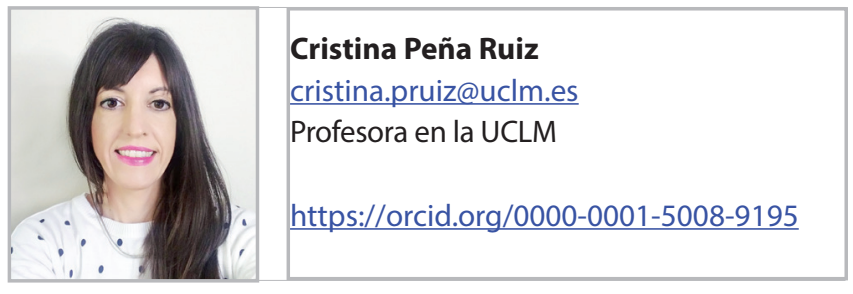

Artículo enviado el 09/11/2021 Artículo aceptado el 04/12/2021

Doctora por la Universidad de Castilla-La Mancha con mención Internacional, sobresaliente Cum Laude en el programa de Investigación en Artes, Humanidades y Educación. Licenciada en Bellas Artes (Premio Extraordinario y Premio Nacional de Educación) y Máster de Investigación en Prácticas Artísticas y Visuales por la UCLM. Diplomada en Conservación y Restauración de Bienes Culturales con las especialidades de escultura y arqueología por la Escuela Superior de Conservación y Restauración de Bienes Culturales de Madrid. Profesora y Conservadora de la colección Parkett de la facultad de Bellas Artes de Cuenca, España. Ha sido la responsable de Conservación, catalogación, diseño de sistemas de gestión de las Colecciones y Archivos de Arte Contemporáneo de la Facultad de Bellas Artes de Cuenca durante el proyecto de investigación financiado por el Ministerio de Economía y Competitividad MINECO HAR 2013-48604-C2-1-P:Creación y estudio de las CAAC de Cuenca como modelo metodológico para una investigación de excelencia en Bellas Artes, 2014-2016, Proyecto FEDER POII-2014002-P:Las colecciones de arte electrográfico y digital del MIDE/ CAAC. Gestión, Conservación, Restauración y divulgación de sus fondos 2014-2016, y con el proyecto MINECO HAR2016-75949C2-1-R, Vocabularios para una Red de Archivos y Colecciones de Media Art y sus efectos: Metaliteracy y Turismo de Conocimiento (VOREMETUR), 2016-2020.

Posee una amplia trayectoria en la conservación y restauración con varias direcciones científicas en proyectos de Investigación en gestión pública y privada. Experiencia en Conservación de Patrimonio en diferentes instituciones como Patrimonio Nacional, Museos Nacionales, Junta de Comunidades de Castilla-La Mancha, Junta de Castilla y León, Junta de Andalucía, Fundaciones, Diputaciones, Galerías de Arte, Ayuntamientos, empresas especializadas en Patrimonio, Universidad, etc., desde la redacción de los proyectos a la dirección de las obras, contando con más de una cuarentena de direcciones en proyectos de conservación. 